\title{
»Nordschleswigsche Siedlungsgenossenschaft G.m.b.H.«
}

et tysk jordkampsforsøg i begyndelsen af 1920'erne

\section{Af Henrik Becker-Christensen}

I 1921 blev der arbejdet med planer om at grundlægge en tysk »koloni« ved Benniksgård i Rinkenæs sogn. Kolonien skulle være et modstød mod den styrkelse af danskheden, som foregik efter Genforeningen. På grundlag af hidtil ukendte akter i Bundesarchiv i Koblenz og i Johs. Schmidts arkiv i landsarkivet i Slesvig fortæller lektor Henrik BeckerChristensen her om denne tidlige fase af jordkampen i 1920'erne.

I en landbrugsdomineret egn som Nordslesvig var det naturligt, at fordelingen af jorden mellem dansk- og tysksindede blev opfattet som et mål for det nationale styrkeforhold. Sådan var det både før og efter 1920. Med Nordslesvigs genforening med Danmark blev de ydre forudsætninger for jordkampen imidlertid radikalt ændret. Det var nu de tysksindede nordslesvigere, som kom i defensiven. For at bøde herpå oprettede de i 1926 med rigstysk støtte Kreditanstalt Vogelgesang, der kom til at betyde en optrapning af jordkampen. Historien herom er velkendt og skal ikke omtales nærmere i denne sammenhæng. Ukendt er derimod et andet initiativ, som mindretallet tog $\mathrm{i}$ begyndelsen af 1920 'erne for at styrke den tyske jordbesiddelse, og det er om dette, der skal fortælles i det følgende. For at forstå baggrunden skal den jordpolitiske situation omkring 1920 først kort ridses op.

De tyske jordtab o. 1920

Med udbruddet af 1 . verdenskrig var der indtrådt en pause i jordkampen, og ved Nordslesvigs afståelse til Danmark forsvandt presset mod den danske jordbesiddelse. Det var i denne situation, at de dansksindede sønderjyder afblæste deres deltagelse i jordkampen. Det skete ved ophævelsen af Nordslesvigsk Kreditforening og Landeværnet. Det kunne de også roligt gøre, da rollerne var blevet byttet om, og det nu var de tysksindede, der var i defensiven. Den preussiske stats opkøb af domænegårde hævnede sig, idet de i 1920 
automatisk tilfaldt den danske stat. Det samme gjaldt også statsskove og præstegårdsjord. Hertil kom opkøb af de augustenborgske godser og flere andre store ejendomme. Tilsvarende solgte adskillige tyske landmænd i disse år deres gårde til danske og flyttede sydpå.

Det betød en stærk reduktion af den storgårdsjord, som havde været $\mathrm{i}$ tysk eje. Mens tyskerne ifølge H.V.Clausen omkring århundredskiftet havde besiddet $54 \%$, var andelen i 1922 faldet til $24 \%$. Målestokken var her gårde med en ejendomsskyld på over $100.000 \mathrm{kr}$. Det store skred var sat ind i 1920 , hvor overdragelsen af domænerne, statsskovene og præstegårdsjorden til den danske stat tegnede sig for to tredjedele af faldet. Den sidste tredjedel skyldtes salg af privatejet jord. Målt $\mathrm{i}$ kroner og ører havde faldet $\mathrm{i}$ den tyske andel af ejendomsværdien været størst i Haderslev amt, hvor de store domænegårde vejede godt til. For amtet som helhed var den tyske andel af storgårdsjorden faldet fra $40 \%$ til $16 \%$. På andenpladsen kom Aabenraa amt, snævert fulgt af Sønderborg amt. I Aabenraa amt havde $76 \%$ af storgårdsjorden tidligere været i tysk eje. $\mathrm{Nu}$ var andelen faldet til $24 \%$. I Sønderborg amt var der på Sundeved siden kun sket et fald fra $47 \%$ til $38 \%$. På Als var skredet større, idet andelen af den tyskejede jord her var faldet fra $68 \%$ til $24 \%$. I Tønder amt var tallene henholdsvis $66 \%$ og $46 \%$. I Aabenraa amt fordelte overdragelsen af storgårdsjord fra tysk til dansk eje sig omtrent ligeligt på jord, som tidligere havde været $\mathrm{i}$ offentlig og privat eje. Det samme var også tilfældet $\mathrm{i}$ Tønder amt, men i mindre målestok. I Sønderborg amt drejede det sig næsten udelukkende om jord, der $i$ tysk tid havde været $i$ offentlig eje. ${ }^{1}$

Hvordan det forholdt sig med de mellemstore og mindre gårde, hvor danskheden i forvejen var langt stærkere repræsenteret, er ikke fundet oplyst. Da det overvejende drejede sig om ejendomme i privat eje, har faldet $i$ den tyske andel dog procentvis været væsentlig mindre, end det var tilfældet med storgårdene. Til rentegårdene afskrev den danske stat sin fra den preussiske tid arvede forkøbsret. ${ }^{2}$

Når man skal se på de tyske jordtab og vurdere deres konsekvenser for mindretallet, må man skelne mellem den jord, der tidligere havde været $\mathrm{i}$ offentlig eje, og den jord der havde været i privat eje. Mindretallet slog selv rask væk tallene sammen - uden tvivl for at gøre større indtryk på de rigstyske myndigheder, men det var to helt forskellige størrelser. Overdragelsen af tysk tidligere offentlig ejet jord til den danske stat udgjorde en langt større andel end den privatejede jord. De 36 domæner lagde alene beslag på 6.366 ha. Statsskove på 50 ha eller derover blev i 1923 af Danmarks Statistik opgjort til i alt 8.306 ha. ${ }^{3}$ Hertil kom så præstegårdsjorden, der ifølge Kirkelig Aarbog udgjorde mindst 4.797 ha, idet der manglede opgivelser fra 7 sogne. Fra tysk side er præstegårdsjordens samlede areal opgjort til $5.650 \mathrm{ha}^{4}$ 
Overdragelsen af disse arealer til den danske stat var en naturlig følge af suverænitetsskiftet og vedrørte ikke umiddelbart mindretallet. Det var $\mathrm{i}$ ejendomsmæssig henseende tyndt befolkede jorder, der stemmemæssigt ikke battede meget. Tilmed fik adskillige af de tyske forpagtere på domanegårdene i første omgang lov til at blive siddende. Når mindretallet alligevel så skævt til den danske stats nyvundne dispositionsret til den offentligejede jord, var det mere frygten for, hvad den i fremtiden kunne bruges til. Domænegårdene, præstegărdsjorden og de opkøbte godser repræsenterede således en jordreserve, som kunne bruges til udstykningsformål. Set fra et tysk synspunkt ventede man sig ikke noget godt heraf. I varste fald ville de nye brug kun blive overtaget af dansksindede. I bedste fald kunne de tysksindede håbe på at få en andel heraf, men under alle omstændigheder ville det øge den danske befolkningsdel og dermed betyde en national udtynding af tyskheden. Det var grunden til, at pastor Schmidt, Georg Vogelgesang, Max Rasch og andre inden for mindretallet var imod de danske udstykningsplaner og opfattede dem som vendt mod de tysksindede. ${ }^{5}$

I første halvdel af 1920 'erne gik det imidlertid langsomt. En opgørelse i februar 1926 viste, at der indtil da var blevet udstykket 268 nye husmandsbrug. De fordelte sig med $100 \mathrm{i}$ Haderslev amt, $78 \mathrm{i}$ Aabenraa amt, 51 i Tønder amt og 39 i Sønderborg amt. Hertil kom nogle få brug, som endnu ikke var afhændede. Sammenlagt tegnede stats- og domænegårdene sig med 162 brug for den største part af udstykningen. Den øvrige del var blevet foretaget af to udstykningsforeninger samt nogle private. ${ }^{6}$ I det følgende tiår kom der dog mere fart i udstykningen. I 1937 var antallet af nyoprettede brug i Nordslesvig siden 1920 kommet op på ca. 1.735 ? $^{\text {? }}$

Mens overdragelsen af den tidligere offentligejede jord til den danske stat $i$ første omgang ikke fik nogen større konsekvenser for de tysksindede, var salget af privatejet jord umiddelbart mere føleligt. Med den sociale struktur, som mindretallet fik efter 1920, var de hjemmetyske bønder blevet et dominerende element $i$ de tyske rækker. En forringelse af deres stilling var det samme som en alvorlig svækkelse af mindretallet. Det var ikke kun stemmerne, der her talte, men også de hjemmetyske bønder som sociale støttepunkter for det kulturelle og politiske arbejde i sognene. Ligesom det tidligere var tilfældet med de dansksindede nordslesvigere, fik ejendomsretten over jorden derfor en afgørende betydning for det tyske mindretal.

Det var således med den største bekymring, at de efterladte i begyndelsen af 1920'erne var vidne til, at mange tysksindede bønder solgte deres gårde til dansksindede og drog sydpå. Hvor mange det drejede sig om vides ikke, men eksempler er der nok af. ${ }^{8}$ Vigtigst $i$ denne sammenhæng var imidlertid indtrykket af at være blevet trængt $\mathrm{i}$ defensiven. Hvis mindretallet fortsat 
skulle hævde sin stilling på landet, endsige gøre sig håb om en kommende grænserevision, var det nødvendigt med modforholdsregler for at bremse tilbagegangen. Det er på denne baggrund, at man skal vurdere den nye fase af jordkampen i 1920'erne.

Set fra et tysk standpunkt var det suverænitetsskiftet i Nordslesvig og den dermed igangsatte udvikling, som tvang mindretallet til at reagere, for ikke at blive alt for svækket. Målt med denne alen var der altså tale om nødværge med den danske stat og de dansksindede som den offensive part. At de sidstnævnte ikke benyttede nogen form for tvang, blev nok erkendt af pastor Schmidt og ligesindede, men det rokkede ikke ved deres opfattelse af, at danskerne ved fortsatte opkøb i betænkelig grad indsnævrede mindretallets spillerum. På dansk side blev mindretallets indsats for at vende nedgangen derimod opfattet som en offensiv. Oprettelsen af Kreditanstalt Vogelgesang i 1926 blev fremstillet som et brud på "... den fredelige og naturlige udvikling«. Dermed fik de tysksindede tillagt skylden for en genoptagelse af jordkampen. Det fremkaldte tilsvarende en mere aktiv dansk optræden, der førte til en yderligere eskalering af kampen om jorden. Sammenfattende må det derfor siges, at det er ørkesløst at diskutere, som det tidligere hidsigt blev gjort, hvem der »åbnede« eller genåbnede jordkampen. Også her gælder det gamle ord, at det sete afhænger af øjnene, der ser.

\section{Udstykningsplanen}

Inden det kom så vidt, at Kreditanstalt Vogelgesang så dagens lys, havde mindretallet giort flere forsøg på at bremse den tyske flugt fra jorden - et af dem var at lede strømmen over $\mathrm{i}$ en række påtænkte nyoprettede brug. Det var her tanken om en tysk »Siedlung«, der optog sindene. Da kendskabet til denne plan var forbeholdt en lille inderkreds, skal den præsenteres nærmere.

Den 12. juli 1921 skrev arkitekt A. Walther i Haderslev til den tyske folketingsmand pastor Schmidt og indviede ham i en udstykningsplan, som Walther selv havde stået fadder til sammen med andre kredse i byen. Tanken var, at potentielle tyske udvandrere $i$ stedet for at vende hjem til riget skulle slå sig ned i en ny udstykningsbebyggelse i Nordslesvig. I et sogn, hvor der i forvejen var et stærkt tysk mindretal, skulle der skaffes jord til formålet. Her kunne enhver tysksindet så bygge sig et hus og ernære sig efter eget ønske. For eksempel kunne, som det hed i beskrivelsen af planen, "... den ene avle grønsager, den anden frugt, en tredje fjerkræ som hoved- eller bierhverv, eller også beskæftige sig helt som håndværker eller på anden måde erhvervsmæs- 
sigt«. Forudsætningen for at det skulle blive til noget var erhvervelsen af et større landområde på omkring 100 ha samt sikring af tilskud til byggeriet. Det sidstnævnte skulle bl.a. ske i Tyskland, hvor forslagsstillerne håbede på at finde hjælpende hænder som tak for, at den tyske stat slap for at genhuse og beskæftige dem, der på denne måde blev i Nordslesvig. Der blev i den forbindelse kalkuleret med et minimum på 100 nybyggere. ${ }^{9}$

I et ledsagende brev havde Walther opfordret pastor Schmidt til at tage kontakt med initiativtagerne og bistå dem med råd og dåd. To dage senere svarede Schmidt tilbage, at han var »overordentlig interesseret«. Penge kunne han dog ikke stille i udsigt med det første. I stedet blev Walther opfordret til at interessere de tyske ungdomsforbund for planen og tage kontakt med Georg Vogelgesang herom. Nogen større aktiv optræden fra mindretalslederens side blev det ikke til i første omgang. Den indskrænkede sig til, at Schmidt lånte Walther noget udstykningslitteratur, som han gerne ville have tilbage inden for tre uger. ${ }^{10} \mathrm{Da}$ murer Max Albrecht i Sønderborg senere på måneden over for Schmidt luftede sine planer om at flytte til Lüneburger Heide, gjorde sidstnævnte ham dog opmærksom på de tyske udstykningsplaner som et alternativ til udvandring. Ligesom det var tilfældet med Walther blev Albrecht også opfordret til at anskaffe sig den nyudkomne bog »Ansiedlungen ohne Anzahlung «. ${ }^{11}$

Uden penge gik det dog ikke. Walther opererede med et overslag på 300.000 $\mathrm{kr}$. for at gennemføre planen. Til dette formål var der blevet udarbejdet nogle vedtægter for det påtænkte foretagende, som havde fået navnet "Nordschleswigsche Siedlungsgenossenschaft G.m.b.H.« med sæde i Haderslev. Der var som tilrådet af pastor Schmidt tale om et andelsforetagende med det formål at fremme og oprette små udstykningsbebyggelser. Hertil kom fælles indkøb af levneds- og driftsmidler samt afsætning af de færdige produkter. Selskabet skulle i organisatorisk henseende have en bestyrelse, et tilsynsråd og en generalforsamling. Bestyrelsen skulle suverænt afgøre, hvem der kunne blive medlemmer. De sidstnævnte skulle hver indbetale $500 \mathrm{kr}$. til den fælles kasse og yderligere hæfte for et tilsvarende beløb.

I august 1921 modtog pastor Schmidt et eksemplar af de nye vedtægter samt en redegørelse for de økonomiske beregninger, der lå til grund for foretagendet. Af et ledsagende brev fremgik det, at »landråd W.«, som han blev kaldt - det var formentlig landråden i Flensborg kreds, Anton Wallroth - personligt ville prøve at fremme sagen i Berlin. ${ }^{12}$ To måneder senere blev disse mundtlige sonderinger fulgt op, da initiativtagerne i Haderslev selv tog kontakt med de berørte parter i Tyskland. Det skete den 18. oktober i form af en længere skrivelse til det slesvig-holstenske Landwirtschaftskammer i Kiel, 


\section{ôtnick: ebeacitignng -}

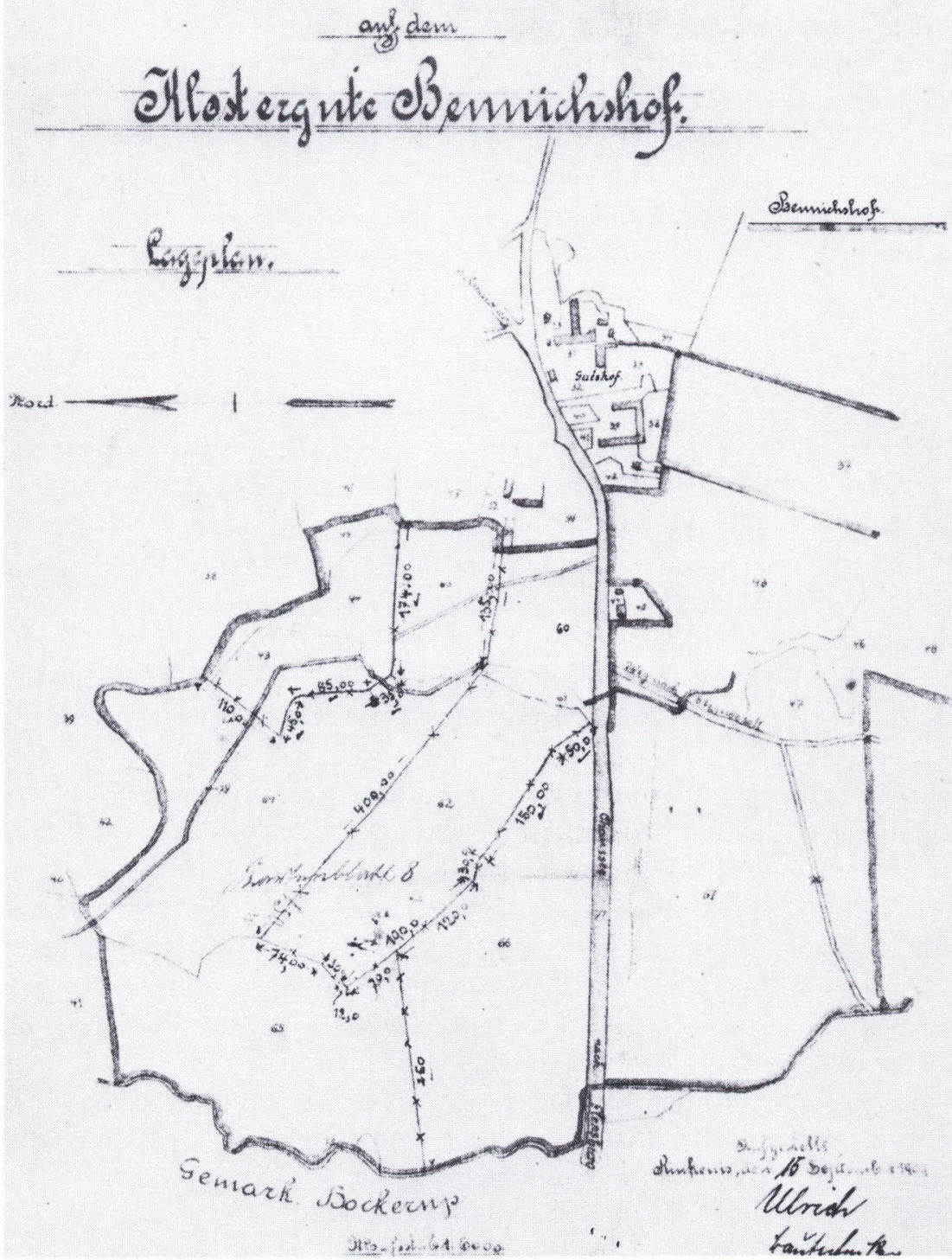

Benniksgård var en stor ejendom, som i 1904 blev overtaget af Klosterkammeret i Hannover. I 1906 var sterrelsen 202 ha. Tegningen over gårdens jorder er dateret 1909. Landsarkivet i Aabenraa. Domaneudvalget/Statens Jordlovsudvalgs kontor i Tonder. Tillag. Ca. 1904-19. Bygningssager vedr. "Klostergodset Benniksgård". 
hvor der blev gjort nærmere rede for planerne. Samme dag sendte Georg Vogelgesang også på Nordschleswigscher Siedlungsvereins vegne en kopi af skrivelsen til Geheimer Oberregierungsrat Werner i Berlin.

I et ledsagende brev til sidstnævnte skrev Vogelgesang, at Siedlungsverein havde brug for et kontant tilskud sydfra på 150-250.000 kr. På grund af de tyske valutavanskeligheder kunne en del af hjælpen dog ydes i naturalier så som byggematerialer og varer. Af skrivelsen til det slesvig-holstenske landbrugsråd fremgik det, at Siedlungsverein nu stilede mod at oprette i alt 150 nye brug med en varierende størrelse på 5-10 ha samt en række helt små. Til dette formål påtænkte foreningen at købe Benniksgård i Rinkenæs sogn, der var ejet af en kulhandler i Flensborg. På et ledsagende kort over gårdens jorder var indtegnet de første 44 parceller på sydsiden af landevejen mellem Gråsten og Kruså. Kortet var indrammet af en patriotisk tekst, hvis ordlyd her skal gengives i originalsproget, da det er med til at sætte de tyske bestræbelser og jordkampen i relief:

"Anno Domini 1921. Wir wollen keine Dänen sein. Wir wollen Deutsche bleiben. Nordschleswigsche Siedlung. $O$ teures Land in Deutschlands Norden. Das deutsch zu bleiben fest begehrt, zeig $\mathrm{Du}$ in Taten und in Worten, dass $\mathrm{Du}$ des Vaterlands Wert. Wir wollen wackre Deutsche sein. Zum Schwur reicht Euch die Bruderhand. Denn Schleswig-Holstein nicht allein, das ganze Deutschland ist mein Vaterland. Der Deutschen Land, trotz Spruch und Brief, Ihr sollts uns nicht verleiden. Wir tragen Mut im Herzen und Schwerter in den Scheiden «.

Åbenbart kneb det imidlertid med at fă folk til at bevidne deres tyskhed på denne måde. I hvert fald skrev Siedlungsverein, at det var meget vanskeligt at få bindende tilsagn fra potentielle tysksindede nybyggere om at deltage $i$ projektet, "... fordi enhver indvender mod os, at en udstykning uden hjælp sydfra lige så lidt kan gennemføres, som en dansk udstykning uden statshjælp.« Denne indvending kunne ifølge Siedlungsverein kun imødegås, hvis der kom faste tilsagn om økonomisk bistand fra Tyskland. ${ }^{13}$

Med denne appel om hjælp var bolden blevet spillet over grænsen til de tyske myndigheder. Dér blev den, selv om pastor Schmidt den 15. december $i$ et brev kunne oplyse, at Vogelgesang havde trukket udstykningsplanen tilbage på grund af finansielle vanskeligheder. Om dette skridt var forårsaget af et rigstysk afslag på ansøgningen to måneder tidligere eller havde rod $\mathrm{i}$ andre forhold, er der ikke fundet belæg for. Til gengæld tog pastor Schmidt nævinte dato af egen drift sagen op igen. I tre enslydende breve til Auswärtiges Amt, det preussiske indenrigsministerium og pastor Nissen i Flensborg, opfordrede Schmidt indtrængende de tyske myndigheder til at støtte de tidligere fremsendte udstykningsplaner. Det blev bl.a. begrundet med, at man her 
kunne slå to fluer med et smæk - flygtningeforsorg og udstykning af nye brug. Ved at forlægge denne indsats til Nordslesvig, ville udvandringen herfra blive bremset og mindretallet styrket. At der var tale om små husmandsbrug gjorde ikke noget, da den »lille mand « ifølge Schmidt var lige så vigtig i den nationale kamp som den mere velstående. Som yderligere belæg herfor kunne han tilføje, "... at til den lille mand hører nu jo navnlig også bærerne af intelligensen og den nationale idealisme. $\kappa^{14}$

Pastor Schmidts indgriben hjalp dog ikke stort. I begyndelsen af januar 1922 skrev han til Vogelgesang, at det ikke så ud til, man kunne opnå nogen støtte gennem flygtningeforsorgen og rigsmidler. Sagen var løbet ind $i$ »bureaukratisk farvand«. I den forbindelse klagede Schmidt over, at den preussiske stat trods al afmagt havde en "latterlig selvfølelse«. At det var tilfældet, kunne Vogelgesang tale med om. Kort tid forinden havde han i forbindelse med udstykningsplanen modtaget en skrivelse fra de tyske myndig-

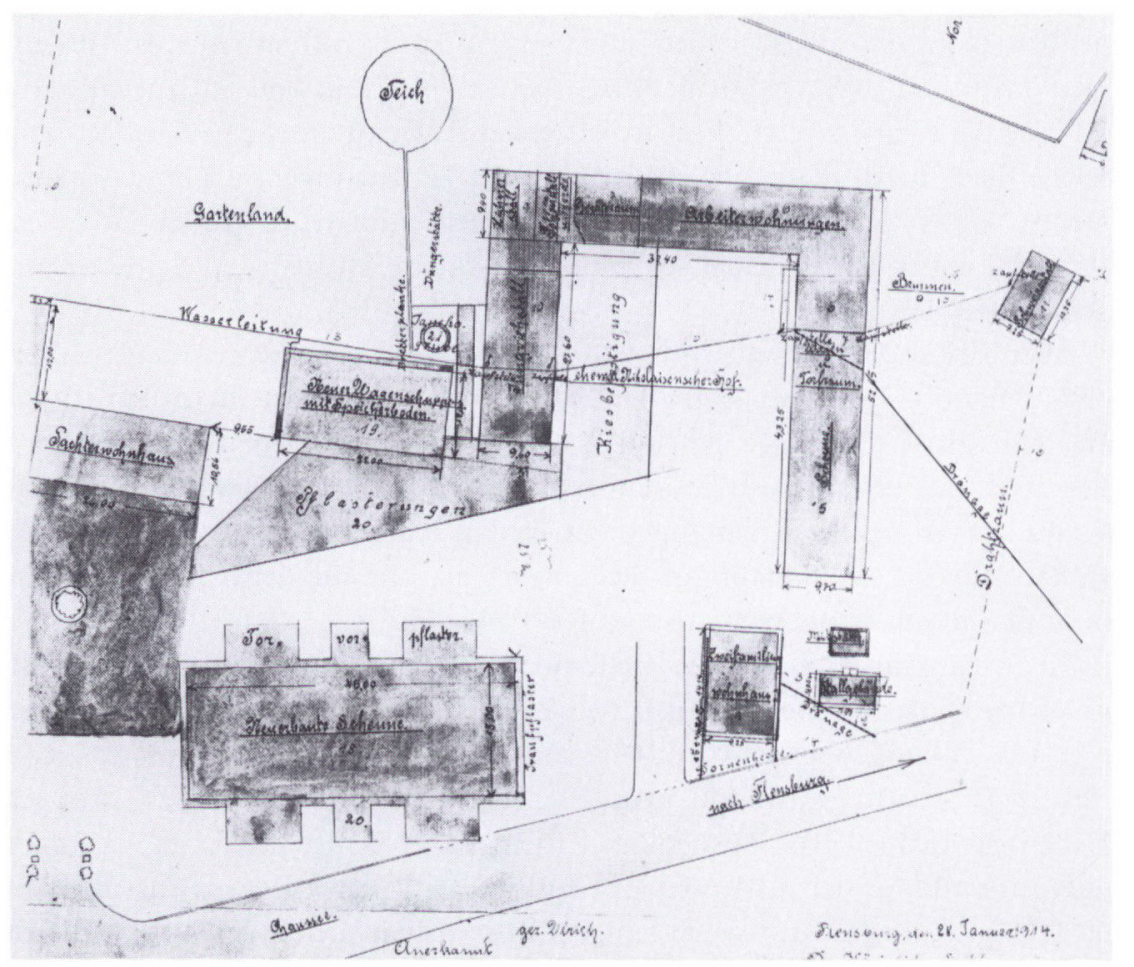

Benniksgårds anselige bygninger er her tegnet $i$ 1914. Malestok 1:500. Landsarkivet $i$ Aabenraa. Domaneudvalget/Statens Jordlovsudvalgs kontor i Tonder. Tillag. Ca. 1904-19. Bygningssager vedr. "Klostergodset Benniksgård". 
heder, hvor de udbad sig en række oplysninger. Vogelgesang havde dog henvist dem til landbrugskammeret i Flensborg. Til pastor Schmidt skrev han herom: "Det er morsomt at læse, hvordan man behandler os som undergivne, jeg tror, det bedste middel derimod er at le. « $^{15}$

Med denne kommentar løb udstykningsplanen ud i sandet. Nok blev Vogelgesang i januar 1922 belemret med en lang række nye detailspørgsmål, men det førte ikke til noget resultat. Fire år senere klagede han tilbageskuende over, at ingen havde taget hans og arkitekt Walthers udstykningsplaner alvorligt. Resultatet var ifølge Vogelgesang, at alle de tyske pensionister var udvandret fra Nordslesvig. Hvis planen var blevet støttet sydfra, var det sket med papirmark. Resultatet ville have været en gældfri koloni. ${ }^{16}$

Med dette udsagn pegede Vogelgesang også indirekte på en af de mulige årsager til, at den nordslesvigske udstykningsplan ikke havde nydt fremme hos de rigstyske myndigheder - markinflationen og det økonomiske kaos i Tyskland i begyndelsen af 1920 'erne. Vogelgesang og Walther havde selv været inde på disse problemer, da de $i$ oktober 1921 foreslog, at en del af støtten sydfra kunne konverteres til naturalier. I de følgende måneder var markens værdi faldet yderligere. Mens ét kg smør 1921 i Kiel kunne købes for 52 mark, hvilket var en fordobling $\mathrm{i}$ forhold til det foregående år, var prisen igen blevet fordoblet i marts 1922. Fra sommeren dette år begyndte det at gå stærkt. I september 1922 var prisen 612 mark, tre måneder senere 3.128 mark. Det følgende år blev det ene nul efter det andet føjet til disse tal. ${ }^{17}$ En af de mange, der med bekymring fulgte denne udvikling var Harboe Kardel i Flensborg. I midten af september 1923 skrev han i sin dagbog, at det blev stadig vildere. For 1 dansk krone kunne han få 40 millioner mark. En måned senere 3 milliarder mark. Da han den 26. oktober fik udbetalt 55 milliarder mark i løn, måtte han straks købe to pund smør for tilsammen 36 milliarder mark, og bruge dette mere værdifaste betalingsmiddel til husleje. ${ }^{18}$ Først med pengereformen det følgende år blev der sat en stopper for dette vanvid.

I takt med den galopperende markinflation svandt mindretallets udsigter til at få økonomisk bistand i Tyskland til støtte for jordkampen. Resultatet var, at den fra tysk side blev ført på et meget lavt blus og var overladt til de frie kræfters spil. Det betød i første halvdel af 1920'erne en fortsat omend mere beskeden glidning i ejerforholdet $i$ dansk favør. Det var således en storm i et glas vand, da nogle tyske opkøb af gårde ved årsskiftet 1923-1924 fik "Dybbøl-Posten« og "Hejmdal« til at råbe vagt i gevær og kræve modforholdsregler. Koret blev istemt af J.H.Schmidt, Vojensgård, der endda gik så vidt som til at udtale, at den der solgte jord til tyskerne "for usle penges skyld«, begik landsforræderi. Også H.P.Hanssen blev mobiliseret og stillede krav om, at der ad lovgivningens vej blev skabt hindringer for udenlandsk opkøb af 
dansk jord. Dog måtte han medgive, at en del af de udenlandske »spekulanter" var tyskere med dansk statsborgerret, der tidligere havde haft jord i Nordslesvig, men solgt den omkring 1920 og rejst sydpå. ${ }^{19}$

Salg af tysk jord til danske blev derimod hilst med stor tilfredshed i den sidstnævnte lejr. Det var f.eks. tilfældet, da de tre herregårde Gammelgård, Rumohrsgård og Werthemine i 1925 blev solgt til den danske stat. Det tyske mindretal havde inden da forsøgt at rejse penge i Tyskland til at sikre ejendommene på tyske hænder, men forgæves. Da salget til staten var en realitet, skrev »Haderslev Stiftstidende« - der ellers ikke var nogen beundrer af den socialdemokratiske regering - anerkendende, at den nationale stilling på Als herved var blevet styrket ganske betydeligt. ${ }^{20}$ Det følgende år var turen kommet til Mariegård ved Jels, hvor forhenværende amtsforstander Carl A.Koch solgte sine 420 tønder land til en dansk ejendomshandler. Salget var bemærkelsesværdigt derved, at Koch tidligere havde været Slesvigsk Partis folketingskandidat i Haderslev kredsen. ${ }^{21}$ Tilsvarende gjorde tre tysksindede bønders salg af deres ejendomme ved Tønder samme forår dybt indtryk på Harboe Kardel og fik ham til at spørge sig selv, om den nationale disciplin var ved at gå helt i forfald. ${ }^{22}$ Det var begivenheder som disse, der fik mindretallet til at føle sig trængt i defensiven og som var medvirkende til oprettelsen af Kreditanstalt Vogelgesang senere på året.

\section{FORKORTELSER}

S.-H.L. $=$ Schleswig-Holsteinisches Landesarchiv, Gottorp

ADVN = Archiv Deutsche Volksgruppe Nordschleswig, Aabenraa

BK $=$ Bundesarchiv Koblenz

\section{NOTER}

1. Hejmdal 28.12.1922. Aftrykt i Grænsevagten V pp. 205-208.

2. Fra dansk side foreligger der ikke nogen statistisk opgørelse over de samlede tyske jordtab i årene omkring genforeningen. Fra tysk side er nævnt flere tal for perioden fra 1919 til 1926 svingende mellem 15.492 ha og 25.997 ha. (Franz v. Jessen: Haandbog III p. 448. Ernst Siegfried Hansen: Disteln am Wege, 1957 p. 177). Det sidstnævnte tal indbefattede 12.028 ha domæneog præstegårdsjord. Disse tal lader sig for den private jords vedkommende ikke verificere, men er fra dansk side anset for at være for høje.

3. F.v.Jessen: Haandbog III p. 434. Statistiske Meddelelser, 4. række 74. bind 1. hefte p. 59.

4. Kirkelig Aarbog 1923, pp. 115-123. Tallene for de enkelte sogne bygger her på en spørgeskemaundersøgelse. Ifølge den udgjorde præstegårdsjorden i Nordslesvig 4.490 ha samt 557 td. Tilsammen giver det de nævnte 4.747 ha. Som næunt havde 7 sogne ikke svaret p\&̊, hvor meget jord, der hørte til kirken. Det angivne tal tager heller ikke højde for eventuelle køb eller salg af præstegårdsjord mellem 1920-22. Nogen udstykning var der dog næppe tale om. Se herom 
"Aktstykker vedrørende Kreditanstalt Vogelgesangs tilblivelse«, p. 78 note 3 samt Sønderjydske Aarbøger 1924 p. 296 og Sønderjydske Aarbøger 1925 p. 307. Den tyske angivelse findes i Ernst Siegfried Hansen: Disteln am Wege, p. 177.

5. Deutscher Volkskalender für Nordschleswig 1925, p. 21. Rigsdagstidende: Forhandlinger i Folketinget, 77de ordentlige Samling 1924-25, II pp. 5513-5516, 6470. Aktstykker vedrorende Kreditanstalt Vogelgesangs tilblivelse, p. 69. Abt. $399.71 \mathrm{nr}$. 170, betænkning 12.9.1924 af Vogelgesang om $»$ deutsche Siedlung im abgetretenen Nordschleswig« (S.-H.L.).

6. Hejmdal 3.2.1926. Se også Tage Nissen: Den sønderjyske udstykning 1920-1928, pp. 18-42.

7. Franz v. Jessen: Haandbog, III pp. 445-447.

8. Se f.eks. Hans J. Muusmann: Stavedskov-Ejstrup-Kragelund, 1980 s. $112 \mathrm{ff}$.

9. Abt. 399.71 nr. 239, brev 12.7.1921 fra A. Walther til pastor Schmidt (S.-H.L.).

10. Ibid., brev 14.7.1921 fra Schmidt til A. Walther.

11. Ibid., brev 30.7.1921 fra Schmidt til Albrecht.

12. Abt. $399.71 \mathrm{nr}$. 239, brev 9.8. og 23.8.1921 fra Walther til Schmidt (S.-H.L.). I sidstnævnte brev skrev Walther, at de økonomiske beregninger var blevet sendt »til Flensborg«. Det er også med til at pege på Wallroth, som den talsmand over for de tyske myndigheder, som mindretallet satte sin lid til.

13. R $43 \mathrm{I} / 385,18.10 .1921$ (BK).

14. Abt. $399.71 \mathrm{nr} .170$, brev 15.12 .1921 (S.-H.L.).

15. Abt. $399.71 \mathrm{nr}$. 78, brev 29.12.1921 fra Vogelgesang til Schmidt og brev 4.1.1922 fra Schmidt til Vogelgesang (S.-H.L.).

16. Abt. 399.71 nr. 32, brev 20.8.1926 fra Vogelgesang til pastor Schmidt (S.-H.L.).

17. En oversigt herover findes $\mathrm{i}$ 》Quellen zur Geschichte Schleswig-Holsteins« III, 1982 p. 24.

18. N.X. Harboe Kardel: Tagebücher 17.9., 21.10. og 26.10.1923 (ADVN).

19. Dybbøl-Posten 15.12.1923, Hejmdal 31.1.1924, Flensborg Avis 13.2.1924, Dannevirke 11.2.1924.

20. Haderslev Stiftstidende citeret efter Grænsevagten VII pp. 375-376. Om det tyske forsøg på at rejse penge til køb af gårdene se Abt. $399.71 \mathrm{nr}$. 72, brev 1.10.1925 (S.-H.L.).

21. Grænsevagten VIII p. 157.

22. N.X.Harboe Kardel: Tagebücher 17.5.1926 (ADVN). 
